\title{
Co-infection of tuberculosis and parasitic diseases in humans: a systematic review
}

Xin-Xu Li, ${ }^{1,2}$ and Xiao-Nong Zhou ${ }^{1 *}$

\begin{abstract}
Co-infection of tuberculosis and parasitic diseases in humans is an important public problem in co-endemic areas in developing countries. However, there is a paucity of studies on co-infection and even fewer reviews. This review examines 44 appropriate papers by PRISMA from 289 papers searched in PubMed via the NCBI Entrez system (no grey literature) up to December 2012 in order to analyze the factors that influence epidemic and host's immunity of co-infection. The limited evidence in this review indicates that most common parasite species are concurrent with Mycobacterium tuberculosis in multiple organs; socio-demographics such as gender and age, special populations with susceptibility such as renal transplant recipients, patients on maintenance haemodialysis, HIV positive patients and migrants, and living in or coming from co-endemic areas are all likely to have an impact on co-infection. Pulmonary tuberculosis and parasitic diseases were shown to be risk factors for each other. Co-infection may significantly inhibit the host's immune system, increase antibacterial therapy intolerance and be detrimental to the prognosis of the disease; in addition, infection with parasitic diseases can alter the protective immune response to Bacillus Calmette-Guerin vaccination against Mycobacterium tuberculosis.
\end{abstract}

Keywords: Tuberculosis, Parasitic diseases, Co-infection

\section{Introduction \\ Rationale}

Both tuberculosis (TB) and parasitic diseases in humans are infectious diseases that exhibit an extensive distribution, causing serious harm to humans. The World Health Organization Special Programme for Research and Training in Tropical Diseases (WHO TDR) provided the TDR disease portfolio in 1999 to deal with the deterioration in the health situation, including leprosy, TB and eight kinds of parasitic diseases, such as malaria, schistosomiasis, etc. [1]. WHO estimated that there was about one third of the global population infected by TB, and in 2010, there were an estimated 8.8 million incident cases of TB globally, mostly occurring in Asia (59\%) and Africa (26\%) [2]. Meanwhile, in 2009 WHO also reported that there were an estimated 225 million malaria cases, mainly distributed in Africa (78\%), South-East Asia (15\%) and the Eastern Mediterranean (5\%) [3]. In 2012, there were an estimated

\footnotetext{
* Correspondence: xiaonongzhou1962@gmail.com

'National Institute of Parasitic Diseases, Chinese Center for Disease Control and Prevention, Key Laboratory of Parasite and Vector Biology, Ministry of Health, WHO Collaborating Centre for Malaria, Schistosomiasis and Filariasis, Shanghai 200025, P. R. China

Full list of author information is available at the end of the article
}

436 million people at risk of Schistosomiasis haematobium infection in Sub-Saharan Africa, of which 112 million were infected, with an estimated 393 million people at risk of Schistosomiasis mansoni infection, of which 54 million were infected [4]; an estimated 120 million people in tropical and subtropical areas of the world were infected with lymphatic filariasis in 2009 [5]. These figures suggest that there is an overlap of endemic regions between TB and parasitic disease, which may lead to co-infection of these diseases in the population.

The earliest report we found was from 1945 and interpreted how to treat a pulmonary TB (PTB) case running concurrently with malaria [6]. A report from 1946 described co-existence of TB with hookworm [7]. The co-infection of TB and parasitic diseases have been reported in many studies for almost the past 70 years, although great achievements have been gained in the fields of TB and parasitic disease control and prevention respectively [2-5]. Up to 2012, some cases of co-infection between TB and parasitic diseases were reported around the world [8-29], and some epidemiological surveys of co-infection in hospitals or communities were carried out [30-34]. Some of these studies showed that the 
immune response was modified in the co-infection situation [35-51].

Inevitably, co-infection would increase the complexity of control and prevention on TB and parasitic diseases. The current systematic reviews on the co-infection of $\mathrm{TB}$ and parasitic diseases help to clarify the complexity of co-infections; however, there are only a few systematic reviews on co-infection. We only found that Enwere et al. [35] reviewed the host response of co-infection between TB and malaria and 4 reviews focused on the influence of chronic helminth infections on immunity against TB $[44,45,47,48]$.

\section{Objectives}

This paper reviewed studies globally over the past 70 years on the co-infection of TB and parasitic diseases using Preferred Reporting Items for Systematic Reviews and Meta-Analyses (PRISMA) guidelines [52], in order to learn more about which parasites are concurrent with TB, the epidemiological situation regarding co-infection, and the human immune function affected by co-infection.

\section{Methods}

\section{Protocol and registration}

We did not register the protocol for this review.

\section{Eligibility criteria}

Published articles were included if they involved case reports of co-infection with TB and any parasitic diseases in human participants, or epidemiological surveys of coinfection in populations, or clinical or laboratory research on the immune responses during co-infection, were eligible for inclusion in the systematic review. Journal articles published with full text or abstracts in English before 2013 were eligible for inclusion.

\section{Information sources}

We mainly searched PubMed via the NCBI Entrez system (any date to December, 2012) (http://www.ncbi.nlm. nih.gov) for studies on the association between TB and parasitic diseases. We also searched bibliographies of identified reports, including previous reviews, for additional references.

\section{Search}

The search was limited to studies of human beings or animal models and no language limits were applied. The terms that were used as MeSH terms or Direct keywords for the search and our search strategy are described in Table 1. All titles, abstracts and full texts from each of the searches were examined and reviewed.

\section{Study selection}

The study selection process is illustrated in Figure 1.
Table 1 Search strategy and terms used to identify studies on co-infection between TB and common parasitic diseases

\begin{tabular}{|c|c|}
\hline Term & $\begin{array}{l}\text { 1. tuberculosis, 2. parasite, 3. helminth, 4. amoebiasis, } \\
\text { 5. leishmaniasis, 6. trypanosomiasis, 7. giardiasis, 8. trichomoniasis, } \\
\text { 9. malaria, 10. toxoplasmosis, 11. cryptosporidiosis, 12. clonorchiasis, } \\
\text { 13. opisthorchiasis, 14. fasciolopsiasis, 15. fascioliasis, } \\
\text { 16. paragonimiasis, 17. schistosomiasis, 18. sparganosis, } \\
\text { 19. echinococcosis, 20. ascariasis, 21. trichuriasis, 22. enterobiasis, } \\
\text { 23. hookworm, 24. strongyloidiasis, 25. trichinellosis, 26. filariasis, } \\
\text { 27. dracunculiasis }\end{array}$ \\
\hline Stra & $\begin{array}{l}1 \text { and }(2 \text { or } 3 \text { or } 4 \text { or } 5 \text { or } 6 \text { or } 7 \text { or } 8 \text { or } 9 \text { or } 10 \text { or } 11 \text { or } 12 \text { or } \\
13 \text { or } 14 \text { or } 15 \text { or } 16 \text { or } 17 \text { or } 18 \text { or } 19 \text { or } 20 \text { or } 21 \text { or } 22 \text { or } \\
23 \text { or } 24 \text { or } 25 \text { or } 26 \text { or } 27 \text { ) }\end{array}$ \\
\hline
\end{tabular}

Papers that were not co-infection studies, or were not for humans, or were published in non-English language without an abstract in English, were excluded. Eligible papers were tabulated.

\section{Data collection process}

Two reviewers extracted data from each eligible study independently, and differences were resolved by discussion with a third. Extracted data was tabulated on the basis of data items. No formal meta-analysis was carried out and analysis to investigate statistical heterogeneity or publication bias was not performed because most of the studies were case reports and immunological research, and there were very few epidemiological surveys.

\section{Data items}

Data extracted included country, year, co-infection of diseases, sex, age, human immunodeficiency virus (HIV) test and medical history for case reports. For epidemiological

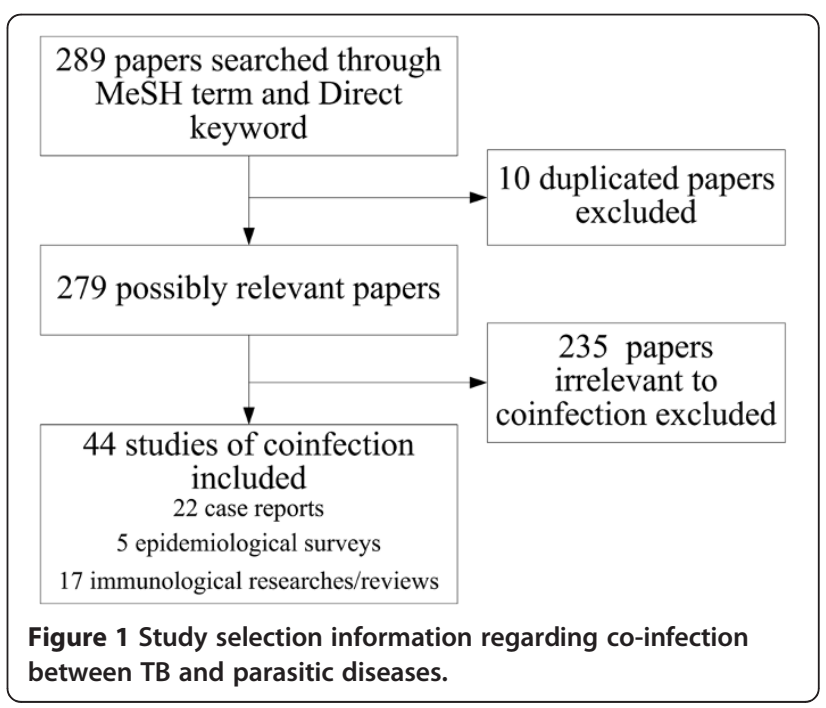


Table 2 Case reports of co-infection between TB and parasitic diseases

\begin{tabular}{|c|c|c|c|c|c|c|c|c|}
\hline Country & $\begin{array}{l}\text { Year of } \\
\text { report }\end{array}$ & Tuberculosis & Parasitic disease & Sex & Age & HIV test & Supplement & $\begin{array}{l}\text { No. of } \\
\text { reference }\end{array}$ \\
\hline Spain & 1996 & Renal TB & Visceral leishmaniasis & Male & 44 years & Negative & Haemodialysis for 19 months & [8] \\
\hline Brazil & 2001 & PTB & Visceral leishmaniasis & Male & 29 years & Negative & Pneumocystis carinii positive & [9] \\
\hline Turkey & 2003 & PTB & Visceral leishmaniasis & Male & 39 years & Negative & Renal transplantation in 2001; Anti-HCV and HCV RNA positive & {$[10]$} \\
\hline India & 2005 & РTB & Visceral leishmaniasis & Male & 37 years & Positive & Tuberculoma of brain & [11] \\
\hline India & 2006 & PTB & Visceral leishmaniasis & Female & 40 years & Positive & & [12] \\
\hline India & 2006 & PTB & Visceral leishmaniasis & Male & 40 years & Positive & & [12] \\
\hline Colombia & 1996 & PTB & $\begin{array}{l}\text { Mucocutaneous } \\
\text { leishmaniasis }\end{array}$ & Male & 50 years & Negative & & [13] \\
\hline France & 2003 & PTB & Cutaneous leishmaniasis & Male & 44 years & Negative & A migrant from Brazil; Polar lepromatous leprosy & [14] \\
\hline Sri Lanka & 2010 & Extrapulmonary TB & Mucosal leishmaniasis & Male & 52 years & Negative & $\begin{array}{l}\text { T-lymphocyte subsets: CD3-437, CD4-237, CD8-146 } \mu \text { l; Serum lgG-532 and } \\
\text { lgM-36 mg/dl }\end{array}$ & {$[15]$} \\
\hline India & 2010 & PTB & $\begin{array}{l}\text { Post-kala-azar dermal } \\
\text { leishmaniasis }\end{array}$ & Female & 25 years & Positive & On treatment for leprosy and PTB for the past 2 months & [16] \\
\hline France & 2000 & Lymph node TB & $\begin{array}{l}\text { Lymph node } \\
\text { trichomoniasis }\end{array}$ & Female & 82 years & Negative & & {$[17]$} \\
\hline India & 2010 & PTB & $\begin{array}{l}\text { Perinatal falciparum } \\
\text { malaria }\end{array}$ & Female & 34 days & Unknown & $\begin{array}{l}\text { Maternal history of falciparum malaria during eighth month of pregnancy; } \\
\text { Father was smear-positive PTB case. }\end{array}$ & [18] \\
\hline Haiti & 1984 & PTB & Toxoplasmosis & Male & 27 years & Unknown & Toxoplasmosis proved fatal and was diagnosed only at autopsy. & [19] \\
\hline Sri Lanka & 2011 & Lymph node TB & $\begin{array}{l}\text { Toxoplasmosis } \\
\text { Toxocariasis }\end{array}$ & Male & 4 years & Negative & & [20] \\
\hline Korea & 2012 & Disseminated TB & Cerebral toxoplasmosis & Male & 24 years & Unknown & A non-Korean engineer with abdominal TB & [21] \\
\hline Australia & 2001 & $\begin{array}{l}\text { PTB Tuberculous } \\
\text { lymphadenitis }\end{array}$ & $\begin{array}{l}\text { Hepatosplenic } \\
\text { schistosomiasis }\end{array}$ & Male & 30 years & & A migrant from the Philippines; A history of alcohol abuse & [22] \\
\hline India & 1991 & PTB & Hydatid disease & Female & 5 years & Unknown & & [23] \\
\hline Turkey & 2002 & PTB & Cardiac hydatid cyst & Female & 52 years & Negative & & [24] \\
\hline China & 2004 & $\begin{array}{l}\text { TB in liver and } \\
\text { abdominal cavity }\end{array}$ & $\begin{array}{l}\text { Liver multiple } \\
\text { hydatidosis }\end{array}$ & Female & 28 years & Negative & & [25] \\
\hline Sudan & 2009 & PTB & Hydatid disease & Female & 25 years & Unknown & In a solitary pulmonary nodule of left lower lobe & [26] \\
\hline China & 2009 & PTB & Liver echinococcosis & Male & 18 years & Unknown & PTB was previously confirmed in 2000 and found relapse in 2008. & [27] \\
\hline China & 2009 & PTB & Liver echinococcosis & Female & 36 years & Unknown & PTB was previously confirmed in 1998 and found relapse in 2008. & [27] \\
\hline Britain & 1994 & PTB & Strongyloidiasis Giardiasis & Male & 31 years & Unknown & A migrant from Gambia; Being resident in the United Kingdom for two years & [28] \\
\hline India & 2001 & TB verrucosa cutis & Filarial elephantiasis & Male & 55 years & Unknown & & [29] \\
\hline
\end{tabular}

Abbreviations: HIV = human immunodeficiency virus; PTB = pulmonary tuberculosis; $\mathrm{HCV}=$ hepatitis $\mathrm{C}$ virus; RNA = ribonucleic acid; $\mathrm{CD}=$ cluster of differentiation; $1 \mathrm{~g}=$ immunoglobulin. 
surveys, the detailed information included was country, year, survey site, number of population screened, number of people with PTB, number of people with parasitic disease, number of people co-infected and prevalence. For clinical or laboratory research on immunity during coinfection, we collected detailed information on country, year, co-infection of disease, subject and conclusions.

\section{Summary measures}

Risk ratios (RR) and their 95\% confidence intervals (CI) were calculated using the Statistical Analysis System (SAS 9.2; SAS Institute Inc., Cary, NC, USA) through Chi square test. All $P$-values of $<0.05$ were taken as statistically significant.

\section{Results}

Two hundred and eighty nine papers were retrieved from the search of published work, of which, 10 were excluded because of duplication and 235 were irrelevant to co-infection with TB and parasitic diseases. Finally, 44 studies of co-infection were included in the analysis, of which, 22 were case reports, 5 were epidemiological surveys and 17 were immunological research/reviews (Figure). There was no grey literature included.

Table 2 summarizes the case reports of co-infection. Twenty-four cases were reported in 22 studies from 13 countries during 1984 to 2012, in which 7 cases were from India. Fourteen studies investigated co-infection with PTB and parasites diseases and 8 studies involved the extrapulmonary $\mathrm{TB}$, such as renal $\mathrm{TB}$, lymph node TB, abdominal TB, TB in liver, tuberculous lymphadenitis and TB verrucosa cutis. The youngest case reported was 34 days old and the eldest case was 82 years old, and the median age of all cases reported was 36 years old. Fifteen of a total 24 cases were male. Ten patients with different clinical conditions co-infected with TB and leishmaniasis were reported, of which, visceral leishmaniasis was the highest. There were also 6 cases coinfected with $\mathrm{TB}$ and hydatid disease. In addition, parasitic diseases accompanied by TB included trichomoniasis, malaria, toxoplasmosis, toxocariasis, schistosomiasis, strongyloidiasis and filarial elephantiasis in different organs. Fourteen of a total of 24 cases reported had been tested for HIV test and 4 were positive.

It can be seen in Table 3 that 5 studies from 3 East African countries and 1 East Asian country were conducted for epidemiology of co-infection between TB and parasitic diseases during 1984 to 2012 . Two studies screened across the general population with 382 and 782 participants in a community and a hospital respectively, one study showed 329 and 215 PTB patients in two hospitals respectively, one study showed 309 PTB patients who were HIV positive and 346 who were HIV negative in a hospital, in the other study, there were 112 smear positive TB patients in a town, whose parasite species involved Entamoeba histolytica, Leishmania donovani, Giardia lamblia, malaria, Clonorchis sinensis, Schistosoma mansoni, taenia species, Ascaris lumbricoides, Trichocephalus trichiurus, hookworm and Strongyloides stercoralis. The prevalence of co-infection between TB and parasitic diseases varied widely among different participants, s species or survey sites.

The interrelationship of infection with $\mathrm{TB}$ and parasitic diseases have been evaluated in Table 4 through two studies screened in the general population, with 382 and 782 participants in a community and a hospital respectively. Those who were Leishmania donovani positive, Giardia lamblia positive or Strongyloides stercoralis positive more easily suffered from PTB than those who were negative and RR values $(95 \% \mathrm{CI})$ were 1.73 (1.142.62), 1.80 (1.10-2.93) and 3.11 (1.53-6.35), respectively. Likewise, persons with PTB were more easily infected by Leishmania donovani, Giardia lamblia or Strongyloides stercoralis than persons without PTB and RR values (95\% CI) were 1.24 (1.08-1.43), 1.86 (1.09-3.16) and 4.26 (1.42-12.77), respectively.

Immunological research of co-infection between $\mathrm{TB}$ and parasitic diseases during 1989 to 2012 are shown in Table 5. In four studies that reported a change of activity of the host's immune system when the course of TB was aggravated by opisthorchiasis invasion, the activity increased at the acute stage of invasion and decreased at the subacute stage or in the chronization. A study from France showed that co-infecton of American cutaneous leishmaniasis, lepromatous leprosy and PTB downregulated the T-helper (Th) 1 cell response. Four studies on coinfection with Mycobacterium tuberculosis (M. TB) and malaria showed that malarial parasites decreased the host's effective humoral and cellular immune responses to $\mathrm{M}$. TB, and co-infection exacerbated chronic TB, suggesting a competitive antagonist effect between heat shock protein 70 (HSP70) from M. TB and adenosine triphosphatebinding protein (ATPBP) of malaria may exist. Two studies suggested that the impact of co-infection between filarial infection and $\mathrm{M}$. TB infection on the immune response was uncertain. Four studies reported immunomodulation characteristics of co-infection beween $\mathrm{TB}$ and intestinal helminths. A study from China indicated that as the echinococcosis chronicity increased, the immune profile in $\mathrm{TB}$ patients changed from a Th1 to Th2 response. In three other studies in which the effect of infection of intestinal parasites and Schistosoma mansoni on the protective immune response to Bacillus Calmette-Guerin (BCG) vaccination against $\mathrm{M}$. TB and the effect of malaria infection on the effectiveness of novel $\mathrm{TB}$ vaccines in protecting against TB were evaluated, the protective efficacy of BCG vaccination was reduced but the effectiveness of novel TB vaccines was unaffected. 
Table 3 Epidemiological surveys of co-infection between TB and parasitic diseases

\begin{tabular}{|c|c|c|c|c|c|c|c|c|c|c|c|c|}
\hline \multirow[t]{2}{*}{ Country } & \multirow{2}{*}{$\begin{array}{l}\text { Year of } \\
\text { report }\end{array}$} & \multirow{2}{*}{$\begin{array}{l}\text { No. of population } \\
\text { screened (a) }\end{array}$} & \multirow{2}{*}{$\begin{array}{l}\text { No. of people } \\
\text { with TB (b) }\end{array}$} & \multicolumn{2}{|c|}{ People with parasitic disease (c) } & \multirow{2}{*}{$\begin{array}{l}\text { No. of people } \\
\text { co-infected (d) }\end{array}$} & \multicolumn{3}{|c|}{ Prevalence (\%) } & \multirow{2}{*}{$\begin{array}{l}\text { Survey } \\
\text { site }\end{array}$} & \multirow[t]{2}{*}{ HIV test } & \multirow{2}{*}{$\begin{array}{l}\text { No. of } \\
\text { reference }\end{array}$} \\
\hline & & & & No. & Species & & $d / a$ & $d / b$ & $d / c$ & & & \\
\hline \multirow[t]{4}{*}{ Korea } & \multirow[t]{4}{*}{1984} & & 329 & & Trichocephalus trichiurus & 68 & & 20.7 & & Hospital1 & Unknown & {$[30]$} \\
\hline & & & 215 & & Trichocephalus trichiurus & 14 & & 6.5 & & Hospital2 & Unknown & \\
\hline & & & 329 & & Clonorchis sinensis & 58 & & 17.6 & & Hospital1 & Unknown & \\
\hline & & & 215 & & Clonorchis sinensis & 13 & & 6.0 & & Hospital2 & Unknown & \\
\hline Sudan & 2004 & 382 & 100 & 252 & Leishmania donovani & 77 & 20.2 & 77.0 & 30.6 & Community & Unknown & {$[31]$} \\
\hline \multirow[t]{10}{*}{ Ethiopia } & \multirow[t]{10}{*}{2006} & 782 & 100 & 234 & Intestinal parasites & 32 & 4.1 & 32.0 & 13.7 & Hospital & Unknown & \multirow[t]{10}{*}[32]{} \\
\hline & & \multirow[t]{2}{*}{782} & \multirow[t]{2}{*}{100} & \multirow[t]{2}{*}{155} & Helminths & \multirow[t]{2}{*}{16} & \multirow[t]{2}{*}{2.0} & \multirow[t]{2}{*}{16.0} & \multirow[t]{2}{*}{10.3} & \multirow[t]{2}{*}{ Hospital } & \multirow[t]{2}{*}{ Unknown } & \\
\hline & & & & & Parasites species & & & & & & & \\
\hline & & 782 & 100 & 88 & Ascaris lumbricoides & 5 & 0.6 & 5.0 & 5.7 & Hospital & Unknown & \\
\hline & & 782 & 100 & 70 & Giardia lamblia & 15 & 1.9 & 15.0 & 21.4 & Hospital & Unknown & \\
\hline & & 782 & 100 & 50 & Entamoeba histolytica & 10 & 1.3 & 10.0 & 20.0 & Hospital & Unknown & \\
\hline & & 782 & 100 & 36 & Hookworm & 6 & 0.8 & 6.0 & 16.7 & Hospital & Unknown & \\
\hline & & 782 & 100 & 25 & Taenia species & 2 & 0.3 & 2.0 & 8.0 & Hospital & Unknown & \\
\hline & & 782 & 100 & 13 & Strongyloides stercoralis & 5 & 0.6 & 5.0 & 38.5 & Hospital & Unknown & \\
\hline & & 782 & 100 & 8 & Trichuris trichiura & 1 & 0.1 & 1.0 & 12.5 & Hospital & Unknown & \\
\hline \multirow[t]{6}{*}{ Tanzania } & \multirow[t]{6}{*}{2007} & & 309 & & Malaria & 19 & & 6.1 & & Hospital & HIV positive & \multirow[t]{6}{*}{ [33] } \\
\hline & & & 309 & & Schistosomiasis & 100 & & 32.4 & & Hospital & HIV positive & \\
\hline & & & 309 & & Hookworm & 33 & & 10.7 & & Hospital & HIV positive & \\
\hline & & & 346 & & Malaria & 9 & & 2.6 & & Hospital & HIV negative & \\
\hline & & & 346 & & Schistosomiasis & 132 & & 38.2 & & Hospital & HIV negative & \\
\hline & & & 346 & & Hookworm & 86 & & 24.9 & & Hospital & HIV negative & \\
\hline \multirow[t]{6}{*}{ Ethiopia } & 2012 & & 112 & & Intestinal helminths & 32 & & 28.6 & & Community & $47 \%(53 / 112)$ of & {$[34]$} \\
\hline & & & 112 & & Ascaris lumbricoides & 12 & & 10.7 & & Community & $\begin{array}{l}\text { PIB patients } \\
\text { were HIV positive }\end{array}$ & \\
\hline & & & 112 & & Hookworm & 8 & & 7.1 & & Community & & \\
\hline & & & 112 & & Schistosoma mansoni & 6 & & 5.4 & & Community & & \\
\hline & & & 112 & & Trichuris trichiura & 8 & & 7.1 & & Community & & \\
\hline & & & 112 & & Strongyloides stercoralis & 3 & & 2.7 & & Community & & \\
\hline
\end{tabular}


Table 4 The interrelationship of infection between TB and parasitic diseases

\begin{tabular}{|c|c|c|c|c|c|c|c|c|}
\hline Country & Year of report & Parasitic disease & & PTB (+) & PTB (-) & $\mathrm{RR}_{\text {row }}(95 \% \mathrm{Cl})$ & $P$-value & No. of reference \\
\hline \multirow[t]{3}{*}{ Sudan } & 2004 & Leishmania donovani & + & 77 & 175 & $1.73(1.14-2.62)$ & & [31] \\
\hline & & & - & 23 & 107 & 1.00 & & \\
\hline & & $\mathbf{R R}_{\text {col }}(95 \% \mathrm{Cl})$ & & $1.24(1.08-1.43)$ & 1.00 & & 0.0067 & \\
\hline \multirow[t]{27}{*}{ Ethiopia } & 2006 & Intestinal parasites & + & 32 & 202 & $1.10(0.74-1.63)$ & & {$[32]$} \\
\hline & & & - & 68 & 480 & 1.00 & & \\
\hline & & $\mathbf{R R}_{\text {col }}(95 \% \mathrm{Cl})$ & & $1.08(0.79-1.47)$ & 1.00 & & 0.6272 & \\
\hline & & Helminths & + & 16 & 139 & $0.77(0.46-1.28)$ & & \\
\hline & & & - & 84 & 543 & 1.00 & & \\
\hline & & $\mathbf{R R}_{\text {col }}(95 \% \mathrm{Cl})$ & & $0.78(0.49-1.26)$ & 1.00 & & 0.3047 & \\
\hline & & Ascaris lumbricoides & + & 5 & 83 & $0.42(0.17-0.99)$ & & \\
\hline & & & - & 95 & 599 & 1.00 & & \\
\hline & & $\mathrm{RR}_{\text {col }}(95 \% \mathrm{Cl})$ & & $0.41(0.17-0.99)$ & 1.00 & & 0.0341 & \\
\hline & & Giardia lamblia & + & 15 & 55 & $1.80(1.10-2.93)$ & & \\
\hline & & & - & 85 & 627 & 1.00 & & \\
\hline & & $\mathrm{RR}_{\text {col }}(95 \% \mathrm{Cl})$ & & $1.86(1.09-3.16)$ & 1.00 & & 0.0233 & \\
\hline & & Entamoeba histolytica & + & 10 & 40 & $1.63(0.90-2.93)$ & & \\
\hline & & & - & 90 & 642 & 1.00 & & \\
\hline & & $\mathbf{R R}_{\text {col }}(95 \% \mathrm{Cl})$ & & $1.70(0.88-3.30)$ & 1.00 & & 0.1145 & \\
\hline & & Hookworm & + & 6 & 30 & $1.32(0.62-2.81)$ & & \\
\hline & & & - & 94 & 652 & 1.00 & & \\
\hline & & $\mathbf{R R}_{\text {col }}(95 \% \mathrm{Cl})$ & & $1.36(0.58-3.19)$ & 1.00 & & $0.4451^{*}$ & \\
\hline & & Taenia species & + & 2 & 23 & $0.62(0.16-2.36)$ & & \\
\hline & & & - & 98 & 659 & 1.00 & & \\
\hline & & $\mathbf{R R}_{\text {col }}(95 \% \mathrm{Cl})$ & & $0.59(0.14-2.48)$ & 1.00 & & $0.7594^{*}$ & \\
\hline & & Strongyloides stercoralis & + & 5 & 8 & $3.11(1.53-6.35)$ & & \\
\hline & & & - & 95 & 674 & 1.00 & & \\
\hline & & $\mathbf{R R}_{\text {col }}(95 \% \mathrm{Cl})$ & & $4.26(1.42-12.77)$ & 1.00 & & $0.0172^{*}$ & \\
\hline & & Trichuris trichiura & + & 1 & 7 & $0.98(0.15-6.17)$ & & \\
\hline & & & - & 99 & 675 & 1.00 & & \\
\hline & & $\mathrm{RR}_{\text {col }}(95 \% \mathrm{Cl})$ & & $0.97(0.12-7.84)$ & 1.00 & & $1.0000^{*}$ & \\
\hline
\end{tabular}


Table 5 Immunological research of co-infection between TB and parasitic diseases

\begin{tabular}{|c|c|c|c|c|c|c|}
\hline Country & $\begin{array}{l}\text { Year of } \\
\text { report }\end{array}$ & Tuberculosis & Parasitic disease/species & Subject & Conclusions & $\begin{array}{l}\text { No. of } \\
\text { reference }\end{array}$ \\
\hline France & 2003 & PTB & $\begin{array}{l}\text { American cutaneous } \\
\text { leishmaniasis }\end{array}$ & $\begin{array}{l}\text { A 44-year-old man with triple infection of } \\
\text { cutaneous leishmaniasis, lepromatous leprosy, } \\
\text { and PTB }\end{array}$ & $\begin{array}{l}\text { Unresponsiveness to IL-12 of patient's T cells after stimulation with } \\
\text { Leishmania guyanensis, M. bovis bacille Calmette-Guerin, and M. leprae } \\
\text { antigens suggested the inability to mount an appropriate Th cell } \\
\text { response to upregulate the IL-12 receptor expression. }\end{array}$ & [14] \\
\hline Gambia & 1999 & M. TB & Malaria & Review & $\begin{array}{l}\text { Malarial parasites can decrease their vertebrate host's effective humoral } \\
\text { and cellular immune responses to M. TB. }\end{array}$ & [35] \\
\hline USA & 2004 & M. TB & Plasmodium yoelii NL & Mice & $\begin{array}{l}\text { Co-infected mice were less able to contain growth of M. TB in lung, } \\
\text { spleen, and liver and had increased mortality. }\end{array}$ & {$[36]$} \\
\hline Thailand & 2006 & M. TB & Plasmodium falciparum & $\begin{array}{l}\text { HSP70 (M. TB) and ATPBP (Plasmodium } \\
\text { falciparum) }\end{array}$ & $\begin{array}{l}\text { HSP70 and ATPBP share a common molecular function as ATP binding } \\
\text { resulting from purine nucleotide binding. Therefore, a competitive } \\
\text { antagonist effect between both molecules can be expected. }\end{array}$ & [37] \\
\hline Germany & 2012 & M. TB & Plasmodium berghei NK65 & An experimental mouse model of co-infection & $\begin{array}{l}\text { Co-infection exacerbated chronic TB while rendering mice less } \\
\text { refractory to Plasmodium. Co-infected animals presented with } \\
\text { enhanced inflammatory immune responses as reflected by exacerbated } \\
\text { leukocyte infiltrates, tissue pathology and hypercytokinemia } \\
\text { accompanied by altered T-cell responses. }\end{array}$ & [38] \\
\hline
\end{tabular}

$\begin{array}{lll}\text { Unknown } 1989 \quad \text { PTB } \quad \text { Opisthorchiasis } & \begin{array}{l}173 \text { patients with PTB complicated by } \\ \text { opisthorchiasis }\end{array}\end{array}$
accompanied by altered T-cell responses.

Among them, activity of the a1-proteinase inhibitor was more frequently higher and carriers of two markers i.e. Hp 2-2 and Gc 1-1 were more frequent.

Unknown 1992 PTB Opisthorchiasis

12 PTB patients concurrent with opisthorchiasis When the course of TB is aggravated by opisthorchiasis invasion, the number of cases of antibacterial therapy intolerance increases and prognosis of the diseases deteriorates. It was shown that the antibacterial and anthelminthic therapy had a favourable clinical and immunologic effect.

Unknown 1992 M. TB Opisthorchiasis Animal

In comparison with the groups of animals with monoinvasion and monoinfection, at the acute invasive phase of mixed pathology ( 2 weeks) the activity of the host's immune system increases, while the biological activities of both pathogens decrease; however, at the subacute phase (2.5 months), all were contrary respectively.

In cases of mixed pathology, at the acute stage of invasion, the immune system showed increased responses with respect to specific and heterologous antigens; in the chronization of invasion the formation of antibodies to heterologous antigens (SRBC) and the level of specific antiopisthorchiasis and anti-TB immune responses decreased together.

As the echinococcosis chronicity increased, the immune profile in both subjects changed from a Th1 to Th2 response. Such an elevated Th2 immune profile, with subsequent suppression of the Th1 immune response, is a common feature of chronic helminth infections.

Chronic filarial infections do not exacerbate M. TB infection in the cotton rat model. It may be possible to develop worm-derived

therapies for autoimmune diseases that do not substantially increase the risk for infections. 
Table 5 Immunological research of co-infection between TB and parasitic diseases (Continued)

\begin{tabular}{|c|c|c|c|c|c|c|}
\hline USA & 2012 & M. TB & Filarial infections & Review & $\begin{array}{l}\text { Filarial infections very clearly alter the magnitude and quality of the } \\
\text { mycobacteria-specific cytokine responses, responses that have been } \\
\text { typically associated with control of these intracellular pathogens. }\end{array}$ & {$[44]$} \\
\hline Denmark & 2007 & TB & Intestinal helminth & Review & $\begin{array}{l}\text { Co-infections cause a range of immunomodulation characterized by } \\
\text { enhanced Th2-type cytokine profiles, high IgE levels and upregulated } \\
\text { regulatory T-cell activity, as well as chronic immune activation. }\end{array}$ & [45] \\
\hline Brazil & 2007 & PTB & Intestinal helminth & 40 PTB patients and 25 healthy controls & $\begin{array}{l}\text { Compared to either TB patients or healthy controls, co-infected } \\
\text { patients' absolute frequencies of } \mathrm{CD}^{+}, C D 4^{+}, C D 8^{+}, N K T \text { cell and CD4 } \\
{ }^{+} \mathrm{CD} 25^{\text {high }} \mathrm{T} \text { cell increased. Differences in } \mathrm{CD}_{4} \mathrm{~T} \text { cell frequencies were } \\
\text { accompanied by lower IFN- } y \text { and elevated and sustained IL-10 levels in } \\
\text { WB cultures from co-infected patients compared to TB patients. }\end{array}$ & [46] \\
\hline Mexico & 2012 & TB & Helminthic infections & Review & $\begin{array}{l}\text { Helminths very clearly alter the magnitude of the mycobacteria-specific } \\
\text { cytokine responses, altering the control of the mycobacteria growth. } \\
\text { Mycobacteria-induced immune responses are suppressed by helminth } \\
\text { infections. }\end{array}$ & {$[47]$} \\
\hline USA & 2012 & TB & Helminths & Review & $\begin{array}{l}\text { Helminth-induced Th2 and T reg responses impinge on host resistance } \\
\text { against M. TB infection. Th1 response is reduced in helminth co- } \\
\text { infected hosts. Helminth-induced alternatively activated macrophages } \\
\text { contribute to enhanced susceptibility to TB. }\end{array}$ & {$[48]$} \\
\hline Brazil & 2002 & $\begin{array}{l}\text { BCG } \\
\text { vaccination }\end{array}$ & $\begin{array}{l}\text { Ascaris lumbricoides, } \\
\text { Entamoeba histolytica, and } \\
\text { Strongyloides stercoralis }\end{array}$ & $\begin{array}{l}14 \text { male students aged } 12-15 \text { years: } 7 \text { having } \\
\text { protozoan or helminthic infections and } 7 \text { free } \\
\text { of intestinal parasites }\end{array}$ & $\begin{array}{l}\text { Th2-like IL-10 responses induced by intestinal parasites may interfere in } \\
\text { BCG-induced Th1-like IFN- } \gamma \text { response. Intestinal parasitic infections may } \\
\text { significantly alter the protective immune response to BCG vaccination. }\end{array}$ & [49] \\
\hline Sweden & 2005 & $\begin{array}{l}\text { BCG } \\
\text { vaccination to } \\
\text { protect against } \\
\text { M. TB }\end{array}$ & S. mansoni & $\begin{array}{l}\text { BCG vaccinated mice with prior S. mansoni } \\
\text { infection }\end{array}$ & $\begin{array}{l}\text { S. mansoni infection reduces the protective efficacy of BCG vaccination } \\
\text { against M. TB possibly by attenuation of protective immune responses } \\
\text { to mycobacterial antigens and/or by polarizing the general immune } \\
\text { responses to the Th2 profile. }\end{array}$ & {$[50]$} \\
\hline USA & 2011 & $\begin{array}{l}\text { TB vaccines in } \\
\text { protecting } \\
\text { against } M . \mathrm{TB}\end{array}$ & Plasmodium yoelii NL & $\begin{array}{l}\text { TB vaccines in a co-infection mouse model of } \\
\text { two pathogens }\end{array}$ & $\begin{array}{l}\text { The effectiveness of novel TB vaccines in protecting against TB was } \\
\text { unaffected by a primary malaria co-infection in a mouse model of PTB. }\end{array}$ & {$[51]$} \\
\hline
\end{tabular}

Calmette-Guerin; L. sigmodontis = litomosoides sigmodontis; $S$. mansoni = schistosoma mansoni. 


\section{Discussion}

This review only found 24 cases of co-infection with TB and parasitic diseases but they distributed widely in 13 countries and covered PTB, extrapulmonary TB, and diseases caused by protozoa and helminths [8-29]. We also found 5 epidemiological studies in which prevalence of co-infection varied widely [30-34], and found that it was evident in 18 studies that the activity of the host's immune system was altered during co-infection happened [27,34-42,44-51]. Therefore, assessing co-infection characteristics, influencing factors and impact on immunity is important to control and prevention whether for TB or parasitic diseases.

About 17 parasite genera concurrent with M. TB were reviewed as case reports, epidemiological surveys and immunological research, which were divided into protozoa (Entamoeba [32,49], Leishmania [8-16,31], Giardia lamblia [28,32], Trichomonas [17], Plasmodium [18,33,35,37,38], Toxoplasma [19-21]) and helminths (Clonorchis sinensis [30], Opisthorchis [39,40], Schistosoma [22,33,34], Taenia [32], Echinococcus [23-27], Ascaris lumbricoides [32,34,49], Toxocara [20], Trichuris trichiura [30,32,34], Ancylostoma [32-34], Strongyloides stercoralis $[28,32,34,49]$, Filaria [29,43,44]) and covered most of the common parasites species. Of those, leishmaniasis, hydatid disease and malaria were reported to coexist more freuequently with $\mathrm{TB}$ in the human body. In addition to co-infection of $\mathrm{TB}$ and a single parasitic disease, there was also co-infection of TB and multiple parasitic diseases, such as co-infection of pneumocystis carinii pneumonia, visceral leishmaniasis and PTB, coinfection of toxoplasmosis, toxocariasis and $\mathrm{TB}$, and co-infection of strongyloidiasis, giardiasis and TB $[9,20,28]$.

Possibly gender differences exist in co-infection of TB and different parasitic diseases. Among ten cases reported to be co-infected with TB and leishmaniasis, only two cases were female [8-16], however, only one of six cases co-infected with TB and hydatid disease was male [23-27]. In spite of these limited data without epidemiological evidence, we can infer that different social roles associated by gender possibly result in different probabilities of contacting different parasites resulting in different incidence and prevalence. An epidemiological survey in subtropical Ecuador suggested that male gender was one of risk factors associated with cutaneous leishmaniasis [53]. Contrarily, a population-based study in the Hamar of Ethiopia indicated that hydatid disease was a public health problem for women [54]. Irrefutably, gender differentials also exist in the prevalence of TB [55].

Although no significant age clustering was found in 23 cases of co-infecion who had a huge age span ranging from 34 days old to 82 years old [8-29], however, there were fewer reported cases of less than 20 years old and more than 60 years old. Likewise, this limited data were not epidemiological results. Nevertheless, age differentials of co-infection also exist and should not be a neglected factor. A cross-sectional household survey in Sudan showed that percentages of leishmania skin tests and tuberculin positivity by age group increased [31], which possibly reflects that with the increasing age, not only does the immune response increase following exposure to infection but also opportunities of exposure to infection increase gradually.

Among TB patients, prevalence of parasitic disease varies widely in different areas and different survey sites. TB and parasitic disease co-infection is common in clinical practice in East Africa. In Sudan, up to 77\% of TB patients were positive for the leishmania skin test in the community [31]; 32\% of TB patients from hospitals had intestinal parasites and $29 \%$ of TB patients from the community had intestinal helminths in Ethiopia [32,34]; and 32.4$38.2 \%$ of TB patients from hospitals were also infected with Schistosomes in Tanzania [33]. We also noticed the prevalence differentials in Korea, where the infection rates of Trichocephalus trichiurus and Clonorchis sinensis were $20.7 \%$ and $17.6 \%$ respectively among $\mathrm{TB}$ patients in one hospital, but the infection rates were 6.5\% and 6.0\% respectively in another hospital [30]. Among the PTB patients from a hospital in Tanzania, the HIVpositive patients had a significantly lower prevalence of hookworm and Schistosome infection and a higher prevalence of malaria than the HIV-negative patients [33], which indicates HIV also has an impact on prevalence of co-infection.

Therefore, it is no surprise to find many factors that possibly affect co-infection of TB and parasitic diseases. First, socio-demographics, such as gender and age as previously mentioned above, maybe relate to prevalence of co-infection. Second, some special patients, such as renal transplant recipients, patients on maintenance haemodialysis, HIV positive patients and migrants $[8,10-12,14,16,21,22,28,33]$, are likely to be susceptible populations of co-infection. Last but not least, there are higher probabilities of co-infection in some areas with a higher prevalence of $\mathrm{TB}$ and parasitic diseases, such as India and East Africa [11,12,16,18,23,29,31-34]. These might provide useful information to control and prevent co-infection of TB and parasites under the background of very few epidemiological surveys for co-infection to date.

It was observed that PTB and parasitic diseases were risk factors for each other. We analyzed the data of an epidemiological survey in Sudan and found that Leishmaniasis patients had a 1.73 times higher risk for PTB than individuals without Leishmania and PTB patients had a 1.24 times higher risk for Leishmaniasis than individuals without PTB [31]. We also found data from an epidemiological survey in Ethiopia that Giardiasis and 
Strongyloidiasis patients all had higher risks for PTB than persons without Giardia lamblia and Strongyloides stercoralis, respectively, and PTB patients had a higher risk for Giardiasis and Strongyloidiasis than persons without PTB [32].

In comparison with mono-infection, co-infection makes the host's immune system have to deal with a more complex internal environment. The usual manifestation is that clinical signs might become more frequent and serious and therapy may be affected when TB patients are also infected by parasites. Both clinical and laboratory based studies showed that when the course of TB was aggravated by opisthorchiasis invasion, clinical signs of TB became more pronounced, disorders in the functions of the liver and pancreas became more frequent, antibacterial therapy intolerance increased and prognosis of the disease deteriorated $[39,40]$. In order to clarify these situations, some studies were conducted to evaluate the immunopathogenesis of co-infection. Limited data from two studies showed that the immune response of TB patients increased at the acute stage of opisthorchiasis invasion and decreased at the subacute stage or in the chronization $[41,42]$. Two studies indicated that malarial parasites decreased the hosts effective humoral and cellular immune responses to $\mathrm{M}$. TB $[35,36]$, and another study using an experimantal animal model showed co-infection between TB and malaria exacerbated chronic TB while rendering mice less refractory to Plasmodium [38]. Another study found that with the increase of echinococcosis chronicity, the immune profile in TB patients displayed an elevated Th2 immune reponse with subsequent suppression of the Th1 immune response [27]. Although one study suggested chronic filarial infections do not exacerbate M. TB infection [43], a review pointed out that filarial infections very clearly alter the magnitude and quality of the mycobacteria-specific cytokine response [44]. Generally, it is observed that the host's immune system is inhibitited to a great extent during co-infection.

Some investigations observed the change of levels of immune indexes during co-infection. A study on coinfection of PTB and opisthorchiasis found that among co-infected patients, activity of the $\alpha 1$-proteinase inhibitor was more frequently higher and carriers of two markers i.e. Hp 2-2 and Gc 1-1 were more frequent [39]. A study on triple infection of leishmaniasis, TB and leprosy showed that patients were unable to mount a Th cell response to upregulate the interleukin-12 receptor expression after stimulation of the triple infection [14]. The investigation of co-infection between TB and intestinal helminths suggested that compared to either TB patients or healthy controls, the absolute frequencies of $\mathrm{CD}^{+}, \mathrm{CD}^{+}, \mathrm{CD}^{+}$, Natural killer $\mathrm{T}$ cell and $\mathrm{CD} 4^{+} \mathrm{CD} 25^{\text {high }} \mathrm{T}$ cell increased in co-infected patients
[46]. Indeed, the change of immune index levels reflects a 'weakened' immune response.

It is worthwhile evaluating the impact of parasitic disease infection on the efficacy of BCG vaccination against M. TB. Ferreira et al. [49] and Elias et al. [50] found that intestinal parasitic infections might significantly alter the protective immune response to BCG vaccination and/or polarize the general immune response to the Th2 profile since Th2-like interleukin-10 responses induced by intestinal parasites might interfere in the BCG-induced Th1-like interferon- $\gamma$ response. Therefore, in areas of high prevalence of co-infection, anti-parasitic chemotherapy prior to immunization may greatly enhance the efficacy of BCG vaccination.

\section{Conclusion}

This review has found limited evidence of factors that influence epidemic and host's immunity of co-infection between TB and parasitic disease in humans. Most of the common parasites species are concurrent with M. TB in multiple organs, which increase antibacterial therapy intolerance and deteriorate prognosis of disease. Sociodemographics such as gender and age, special populations with susceptibility, such as renal transplant recipients, patient on maintenance haemodialysis, HIV positive patients and migrants, and living in or coming from co-endemic areas likely have impacts on co-infection. PTB and parasitic diseases were shown to be risk factors for each other. Co-infection may inhibit the hosts immune system to a great extent. In addition, infection with parasites can alter the protective immune response to BCG vaccination against $M$. TB.

\section{Competing interest}

The authors declare that they have no conflicts of interest.

\section{Authors' contributions}

$X Z$ and $X L$ conceived and designed the review; $X \mathrm{~L}$ conducted the review of the literature, extracted the pertinent data, performed analysis of data, and wrote the first draft of the manuscript; XZ provided strategic advice and assisted with editing of the manuscript. All authors read and approved the final version of the manuscript.

\section{Acknowledgement}

This work is supported in part by National S \& T Major Program (grant no. 2012ZX10004-220)

\section{Author details}

${ }^{1}$ National Institute of Parasitic Diseases, Chinese Center for Disease Control and Prevention, Key Laboratory of Parasite and Vector Biology, Ministry of Health, WHO Collaborating Centre for Malaria, Schistosomiasis and Filariasis, Shanghai 200025, P. R. China. ${ }^{2}$ National Center for Tuberculosis Control and Prevention, Chinese Center for Disease Control and Prevention, Beijing 102206, P. R. China.

Received: 4 January 2013 Accepted: 18 March 2013

Published: 22 March 2013 


\section{References}

1. UNDP, World Bank: WHO Special Programme for Research and Training in Tropical Diseases (TDR): Tropical Disease Research: Progress 1999-2000. Geneva, Switzerland: World Health Organization Press; 2001. WHO/TDR/GEN/01.5.

2. World Health Organization: Global tuberculosis control: WHO report 2011. Geneva, Switzerland: World Health Organization Press; 2011. WHO/HTM/TB/ 2011.16.

3. World Health Organization: World malaria report: 2010. Geneva, Switzerland: World Health Organization Press; 2010.

4. World Health Organization: Schistosomiasis: progress report 2001-2011, strategic plan 2012-2020. Geneva, Switzerland: World Health Organization Press; 2013.

5. World Health Organization: Progress report 2000-2009 and strategic plan 2010-2020 of the global programme to eliminate lymphatic filariasis: halfway towards eliminating lymphatic filariasis. Geneva, Switzerland: World Health Organization Press; 2010. WHO/HTM/NTD/PCT/2010.6.

6. Chatterjee Bahadur GC: How to treat pulmonary tuberculosis case running concurrently with malaria. Indian Med Rec 1945, 65:260-263.

7. Black TC: Coexistent hookworm and tuberculosis. South Med J 1946, 39:881-884.

8. Peces $\mathrm{R}$, de la Torre M, Alcazar R: Visceral leishmaniasis and renal tuberculosis in a patient on maintenance haemodialysis. Nephrol Dial Transplant 1996, 11:707-708.

9. Toledo AC Jr, de Castro MR: Pneumocystis carinii pneumonia, pulmonary tuberculosis and visceral leishmaniasis in an adult HIV negative patient. Braz J Infect Dis 2001, 5:154-157.

10. Ersoy A, Gullulu M, Usta M, Ozcelik T, YImaz E, Uzaslan EK, Vuruskan H, Yavuz M, Oktay B, Dilek K, Yurtkuran M: A renal transplant recipient with pulmonary tuberculosis and visceral leishmaniasis: review of superimposed infections and therapy approaches. Clin Nephrol 2003, 60:289-294.

11. Pandey K, Sinha PK, Ravidas VN, Kumar N, Verma N, Lal CS, Bimal S, Sur D, Bhattacharya SK: Nexus of infection with human immunodeficiency virus, pulmonary tuberculosis and visceral leishmaniasis: a case report from Bihar, India. Am J Trop Med Hyg 2005, 72:30-32.

12. Das VN, Pandey K, Kumar N, Hassan SM, Bimal S, Lal CS, Siddiqui NA Bhattacharya SK: Visceral leishmaniasis and tuberculosis in patients with HIV co-infection. Southeast Asian I Trop Med Public Health 2006, 37:18-21.

13. Escobar MA, Saravia NG, Weigle KA: Concurrent mucosal leishmaniasis and pulmonary tuberculosis. Clin Infect Dis 1996, 23:836-837.

14. Delobel P, Launois P, Djossou F, Sainte-Marie D, Pradinaud R: American cutaneous leishmaniasis, lepromatous leprosy, and pulmonary tuberculosis coinfection with downregulation of the T-helper 1 cell response. Clin Infect Dis 2003, 37:628-633.

15. Rathnayake D, Ranawake RR, Sirimanna G, Siriwardhane Y, Karunaweera N, De Silva R: Co-infection of mucosal leishmaniasis and extra pulmonary tuberculosis in a patient with inherent immune deficiency. Int I Dermatol 2010, 49:549-551.

16. Das VN, Pandey K, Verma N, Bimal S, Lal CS, Singh D, Das P: Post-kala-azar dermal leishmaniasis (PKDL), HIV and pulmonary tuberculosis. Natl Med J India 2010, 23:88-89.

17. Duboucher C, Farto-Bensasson F, Cheron M, Peltier JY, Beaufils F, Perie G: Lymph node infection by Trichomonas tenax: report of a case with coinfection by Mycobacterium tuberculosis. Hum Pathol 2000, 31:1317-1321.

18. Thapa R, Mallick D, Biswas B: Perinatal malaria and tuberculosis coinfection: a case report. Int J Infect Dis 2010, 14:e254-e256.

19. Schroeder HW Jr, Yarrish RL, Perkins TF, Lee C: Sequential disseminated tuberculosis and toxoplasmosis in a Haitian refugee. South Med J 1984, 77:533-534.

20. Guneratne R, Mendis D, Bandara T, Fernando SD: Toxoplasma, toxocara and tuberculosis co-infection in a four year old child. BMC Pediatr 2011, 11:44.

21. Hwang EH, Ahn PG, Lee DM, Kim HS: Cerebral toxoplasmosis combined with disseminated tuberculosis. Journal of Korean Neurosurgical Society 2012, 51:316-319.

22. Torresi J, Sievert W: Hepatosplenic schistosomiasis presenting as granulomatous hepatitis in an immigrant from the Philippines with pulmonary tuberculosis, tuberculous lymphadenitis, and a history of alcohol abuse. J Travel Med 2001, 8:216-218.

23. Karande SC, Sheth SS, Lahiri KR, Shah MD: Coexistent hydatid disease and pulmonary tuberculosis in a five year old girl. J Assoc Physicians India 1991, 39:353-354.
24. Zamani A, Aydemir Y, Gormus N, Odev K, Solak H: Cardiac hydatid cyst in a patient with pulmonary tuberculosis. Int I Tuberc Lung Dis 2002, 6:1033-1034.

25. Chen SY, Du XL, Yan W: A case of liver multiple hydatidosis complicated by tuberculosis in liver and abdominal cavity. Zhonghua Gan Zang Bing Za Zhi 2004, 12:359.

26. Saeed MY, Ahmed AH, Elhassan NB, Elhassan AM: Concomitant tuberculosis and hydatid cyst in a solitary pulmonary nodule of left lower lobe. BMJ Case Rep 2009, 2009:bcr04.2009.1738.

27. Yang YR, Gray DJ, Ellis MK, Yang SK, Craig PS, McManus DP: Human cases of simultaneous echinococcosis and tuberculosis - significance and extent in China. Parasit Vectors 2009, 2:53.

28. Dwarakanath AD, Welton M, Ellis CJ, Allan RN: Interrelation of strongyloidiasis and tuberculosis. Gut 1994, 35:1001-1003.

29. Kumar MV, Kaviarasan PK, Thappa DM, Jaisankar JJ: Tuberculosis verrucosa cutis complicating tropical elephantiasis. Indian I Dermatol Venereol Leprol 2001, 67:49-51.

30. Choi WY, Yoo JE, Kim WG, Yun BH, Kim SG, Yoo WH: Prevalence of intestinal helminthic infections and skin tests for paragonimus and clonorchis in tuberculosis patients. Kisaengchunghak Chapchi 1984, 22:209-214.

31. El-Safi SH, Hamid N, Omer A, Abdel-Haleem A, Hammad A, Kareem HG, Boelaert M: Infection rates with Leishmania donovani and Mycobacterium tuberculosis in a village in eastern Sudan. Trop Med Int Health 2004, 9:1305-1311.

32. Manuel Ramos J, Reyes F, Tesfamariam A: Intestinal parasites in adults admitted to a rural Ethiopian hospital: Relationship to tuberculosis and malaria. Scand J Infect Dis 2006, 38:460-462.

33. Range N, Magnussen P, Mugomela A, Malenganisho W, Changalucha J, Temu MM, Mngara J, Krarup H, Friis H, Andersen AB: HIV and parasitic coinfections in tuberculosis patients: a cross-sectional study in Mwanza, Tanzania. Ann Trop Med Parasitol 2007, 101:343-351.

34. Abate E, Belayneh M, Gelaw A, Idh J, Getachew A, Alemu S, Diro E, Fikre N, Britton S, Elias D, et al: The impact of asymptomatic helminth co-infection in patients with newly diagnosed tuberculosis in north-west Ethiopia. PLoS One 2012, 7:e42901.

35. Enwere GC, Ota MO, Obaro SK: The host response in malaria and depression of defence against tuberculosis. Ann Trop Med Parasitol 1999, 93:669-678.

36. Scott CP, Kumar N, Bishai WR, Manabe YC: Short report: modulation of Mycobacterium tuberculosis infection by Plasmodium in the murine model. Am J Trop Med Hyg 2004, 70:144-148.

37. Wiwanitkit V: Co-infection between tuberculosis and malaria: A consideration on interaction of molecules and pathogenesis. J Vector Borne Dis 2006, 43:195-197.

38. Mueller AK, Behrends J, Hagens K, Mahlo J, Schaible UE, Schneider BE: Natural transmission of Plasmodium berghei exacerbates chronic tuberculosis in an experimental co-infection model. PLoS One 2012, 7:e48110.

39. Vasil'ev AV, Shenderova RI, Ginzburg ZI, Vasil'ev VI: Tuberculosis of the lungs complicated by opisthorchiasis under conditions of the extreme north. Probl Tuberk 1989, 6:41-44.

40. Kashuba EA, Rusakova LI: Anthelmintic therapy of opisthorchiasis in patients with active tuberculosis. Probl Tuberk 1992, 3-4:33-36.

41. Kalenova LF, Zolotukhin VA, Kashuba EA, Kostina GI, Postnikova TF: The formation of host-parasite relationships in an experimental mixed pathology of opisthorchiasis-tuberculosis as dependent on the phase of the Opisthorchis infestation. Zh Mikrobiol Epidemiol Immunobiol 1992, 4:20-22.

42. Kashuba EA, Podkletnova LF, Stepanova TF, Chebysheva EV: Functioning of opisthorchiasis-tuberculosis parasitocenosis at different stages of invasion (experimental investigation). Zh Mikrobiol Epidemiol Immunobiol 2003, 1:17-23.

43. Hubner MP, Killoran KE, Rajnik M, Wilson S, Yim KC, Torrero MN, Morris CP, Nikonenko B, Blanco JC, Hemming VG, Mitre E: Chronic helminth infection does not exacerbate Mycobacterium tuberculosis infection. PLoS Negl Trop Dis 2012, 6:e1970.

44. Metenou S, Babu S, Nutman TB: Impact of filarial infections on coincident intracellular pathogens: Mycobacterium tuberculosis and Plasmodium falciparum. Curr Opin HIV AIDS 2012, 7:231-238.

45. Elias D, Britton S, Kassu A, Akuffo H: Chronic helminth infections may negatively influence immunity against tuberculosis and other diseases of public health importance. Expert Rev Anti Infect Ther 2007, 5:475-484. 
46. Resende Co T, Hirsch CS, Toossi Z, Dietze R, Ribeiro-Rodrigues R: Intestinal helminth co-infection has a negative impact on both antiMycobacterium tuberculosis immunity and clinical response to tuberculosis therapy. Clin Exp Immunol 2007, 147:45-52.

47. Mendez-Samperio P: Immunological mechanisms by which concomitant helminth infections predispose to the development of human tuberculosis. Korean J Parasitol 2012, 50:281-286.

48. Rafi W, Ribeiro-Rodrigues R, Ellner JJ, Salgame P: Coinfection-helminthes and tuberculosis. Curr Opin HIV AIDS 2012, 7:239-244.

49. Ferreira AP, Aguiar AS, Fava MW, Correa JO, Teixeira FM, Teixeira HC: Can the efficacy of bacille calmette-guerin tuberculosis vaccine be affected by intestinal parasitic infections? J Infect D 2002, 186:441-442. author reply $442-443$

50. Elias D, Akuffo H, Pawlowski A, Haile M, Schon T, Britton S: Schistosoma mansoni infection reduces the protective efficacy of BCG vaccination against virulent Mycobacterium tuberculosis. Vaccine 2005, 23:1326-1334.

51. Parra M, Derrick SC, Yang A, Tian J, Kolibab K, Oakley M, Perera LP, Jacobs WR, Kumar S, Morris SL: Malaria infections do not compromise vaccineinduced immunity against tuberculosis in mice. PLoS One 2011, 6:e28164.

52. Liberati A, Altman DG, Tetzlaff J, Mulrow C, Gotzsche PC, loannidis JP, Clarke M, Devereaux PJ, Kleijnen J, Moher D: The PRISMA statement for reporting systematic reviews and meta-analyses of studies that evaluate health care interventions: explanation and elaboration. PLoS Med 2009, 6:e1000100

53. Armijos RX, Weigel MM, Izurieta R, Racines J, Zurita C, Herrera W, Vega M: The epidemiology of cutaneous leishmaniasis in subtropical Ecuador. Trop Med Int Health 1997, 2:140-152.

54. Klungsoyr $P$, Courtright $P$, Hendrikson TH: Hydatid disease in the Hamar of Ethiopia: a public health problem for women. Trans $R$ Soc Trop Med Hyg 1993, 87:254-255.

55. Sharma PP, Kumar A, Singh P: A study of gender differentials in the prevalence of tuberculosis based on NFHS-2 and NFHS-3 data. Indian J Community Med 2010, 35:230-237.

doi:10.1186/1756-3305-6-79

Cite this article as: Li and Zhou: Co-infection of tuberculosis and parasitic diseases in humans: a systematic review. Parasites \& Vectors 2013 6:79.

\section{Submit your next manuscript to BioMed Central and take full advantage of:}

- Convenient online submission

- Thorough peer review

- No space constraints or color figure charges

- Immediate publication on acceptance

- Inclusion in PubMed, CAS, Scopus and Google Scholar

- Research which is freely available for redistribution 